\title{
Alternative assessment to enhance theological education
}

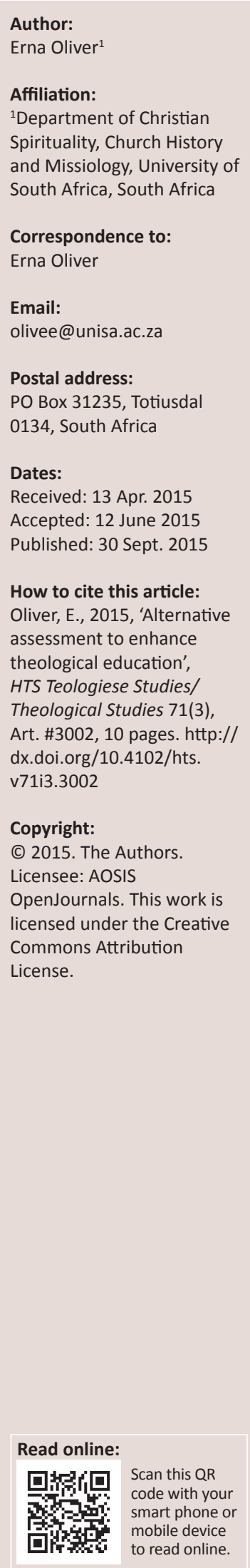

The knowledge driven, network society that is founded upon technology, demands from students to become independent, confident and motivated life-long, self-directed learners that can transfer their knowledge, skills and values. In order to deliver this type of graduates from a diverse and unequal student pool, effective education must be provided. Educators are encouraged to focus education on student-centeredness and to use technology effectively. Alternative assessment methods that are technology driven could enable both educators and students to become more effective in this environment. This article advocates the use of alternative assessment methods by using technology driven assessment tools for possible replacement of traditional, paper based and 'one size fits all' assessment methods within theology. The SECTIONS framework was used to evaluate ten alternative assessment tools that are in accord with the development within society.

\section{Introduction}

The world is changing from an industrial-based society to an information-based society (Pillay 2010:2), and with this move the general expectations regarding higher education are also changing. Education is currently also experiencing a major revolution, the fourth of its kind (Warschauer \& Matuchniak 2010:179). As with the first three revolutions (language, writing and printing), the move towards a network society (the fourth revolution) will have a major impact on education by adding large volumes of new and different methods and tools for knowledge development and skills transferral. Although the fourth revolution already influenced society for a fair number of years, it seems as if the impact that the network society and technology could have on higher education is not yet fully understood or researched (Greenhow, Robelia \& Hughes 2009). A third major challenge for higher education in Africa is to provide effective education for a society that is fragmented on all levels, such as access to and costs of technology, basic education standards and financial resources to name but a few - but also aspiring to become part of the information-based society where the effective use of technology by everyone could be taken for granted. Numerous universities are currently striving towards improving the quality of teaching and learning in order to provide solutions for these challenges.

Universities need to cater for the increased use of technology that fuels the network society. Technology fluency is both a requirement to succeed in education and after graduation. Universities cannot afford to produce graduates without digital literacy ${ }^{1}$ skills 'who are not ready for a world in which the flows and qualities of information and data are fast, contested and fluid' (Prinsloo 2011:1). The incorporation of technology in the curriculum and in education policies should be driven by pedagogical, research and community directed needs and not by technological determinism (Pariser 2011). It should also be kept in mind that the use of technology as an educational tool does not automatically enhance teaching and learning. The technology used should support learning and competency development and it must be well related to the stated educational outcomes and assessment criteria of the course or programme. Competencies associated with the use of technology should support the development of life-long education, which is becoming increasingly important for both the students and for the communities in which they work and live.

Paradigm shifts are therefore taking place within the education system to incorporate the use of technology. Since 2009, there is a move towards the use of mobile technology to aid and support education (Wheeler 2014:9). This move is supported by the fact that a large number of people have access to mobile technology. The majority of the world population $(87 \%)$ has

1.The term 'digital literacy' was coined by Paul Gilster in 1997 and refers to the skills and competencies needed to access and interact
with information from digital sources. Skills include cognitive, motoric, sociological and emotional abilities (Eshet 2012:267). The four with information from digital sources. Skills include cognitive, motoric, sociological and emotional abilities (Eshet 2012:267). The four
core competencies listed are internet searching, hypertext navigation, knowledge assembly and content evaluation (Koltay 2011:216). 
mobile phones whilst only $16 \%$ have access to computers and laptops (Cochrane et al. 2012:204). Although nearly $90 \%$ of B.Th. students at the University of South Africa (UNISA) use cell phones, less than 50\% have Internet access (Oliver 2012:171). If higher education should move to mobile learning, the focus of research will have to be on the way students are using mobile technology and social media will have to be categorised and evaluated for incorporation into teaching and learning practices (Cochrane et al. 2012:204).

The need for change and adaptation in higher education is extensive. Content is rapidly expanding; opening up an ever-growing number of messages (content) and possible interpretations for students to access and evaluate, or to use for creating new content. Methods through which knowledge and skills are transferred are also changing and expanding. Educational methodology constantly needs adjustment and development to stay relevant and applicable. Therefore, survival for higher education does not lie in a single technological paradigm shift, but in adaptation of and commitment to a process of continual change (Ice 2010:158).

This article reflects on incorporating some of the tools provided by technology to enhance assessment in the quest to provide effective education for undergraduate students in Theology at an Open Distance Universities. Short notes on what effective assessment entails are followed by an explanation why alternative assessment is needed. A few alternative assessment tools that can replace the traditional paper based, 'one size fits all' assessment in theology at the University of South Africa are identified and evaluated in order to enhance effective education that is in sync with the needs and expectations of our students (both premillennium and millennium generation ${ }^{2}$ ) and other stakeholders such as communities and churches. Results from this investigation could be generalised and applied to other courses and programmes in theology and wider on Open Distance Higher Education.

\section{The quest for effective education}

Effective education is a creative combination of teaching, learning and assessment that results in positive learning outcomes and competent graduates. This is done through high level and frequent communication, active learning activities and clear and focussed assessment tasks. Effective education should be student-centred, assessment-centred, competency-centred and community directed (eds. Bransford, Brown \& Cocking 2000:153). The aim is to develop lifelong learners who are able to transfer their knowledge and skills and enhance behavioural change (Mayer-Mihalski \& DeLuca 2009); all of which are important building blocks for theological education.

\footnotetext{
2.The student profile (Oliver 2012) shows that both people born before 1980 (premillennial generation) and people born after 1980 (millennium generation) (premillennial generation) and people born after 1980 (millennium generation) form part of the student body. Those born before 1980 are used to a paper based learning style and traditional assessment methods whilst the younger generation is familiar with the digital world and living in a network society. Jukes and Dosaj (2005) are convinced that the traditional learning approaches are not in harmony with the needs and expectations of this generation.
}

The triangle of effective education is constructed by teaching and learning that forms the bottom axe with assessment linking these two aspects to the panicle to create a triangle. Although learning is usually seen as the focus point of education, it is assessment that determines whether learning actually took place and if the student is able to implement the learning through higher levels of cognitive skills. In order to enhance effective education in the network society, the way students learn should change (e.g. from knowledge hoarding and retention to capacity building), and this should be done by changing assessment tasks and methods (Wilson 2013:193), because from a student point of view, assessment determines the actual curriculum (Ramsden 1992:187).

\section{Assessment}

\section{Why traditional assessment should change}

Assessment is a goal-orientated evaluation process that should, if done in close relationship with clear, focussed and implementable learning outcomes, be able to improve and advance learning (Assessment Reform Group 2002; Astin et al. 1996). The primary purpose is to help students to learn better (Fink 2013:93) and to use what they have learned in their daily lives. Braun et al. (2006) state that the purpose of assessment is not to test knowledge retention, but to evaluate the students' ability to demonstrate what they can do with the knowledge gained.

Effective assessment has, according to Blumberg (2014:44), three characteristics. First and foremost, assessment should convey a commitment to helping students to acquire knowledge, skills and values. Secondly, assessments should act as learning events. Thirdly, assessment should enable students to recognise and monitor their own progress. If these three aspects are kept in mind when designing and constructing courses, assessment could improve the quality and impact of education, enabling students to become independent, build their confidence and increase their motivation levels.

Assessment should further also evaluate the development and change of values, attitudes and behaviour that influence both academic success and life beyond and outside the formal educational environment. In order to do this, assessment should consist of a diverse array of methods and focus areas to reveal change, growth and increasing degrees of integration over time (ARG 2002).

The way in which assessment activities are designed and integrated with content and learning activities can have a significant impact on students' motivation, their approach to and experience of learning (Cooper, Orrell \& Bowden 2010). Doyle (2011) states correctly that:

[C]olleges and universities work hard to define the skills and knowledge they want their graduates to have, but unfortunately they use traditional assessment tools that often don't measure whether the learning has occurred. (p. 45) 
Traditional assessment tasks are not always properly linked to each and every learning outcome and the set assessment criteria. The learning outcomes and assessment criteria are not always clearly and sufficiently communicated to the students in understandable, userfriendly language (Race 1999). Variations in marking and inadequate feedback also affect the quality and impact of assessment tasks. Traditional assessment tasks are often formulated in such a way that it does not leave room for creativity, student choices or the use of technology. Traditional assessment in theology at UNISA consists of two essay type assignments and one venue based examination, also focussed on essay type questions. The challenge is to implement appropriate alternative assessment methods to replace the paper based traditional assessment methods that focus mostly on knowledge retention and mainly on one learning style. Assessment would need to change from focussing on the grading of students and assessment of learning to providing interactive learning opportunities (assessment for learning).

\section{What is alternative assessment and how can it enhance effective education}

Alternative assessment means that students have a choice regarding the form and content they provide (North Central Regional Educational Laboratory n.d.) to offer proof to the educator that effective learning did occur. Alternative assessment is an umbrella term that can include various and wide ranging options. It should enable students to move beyond curriculum-bounded knowledge retention and skill acquirements towards building capacity and capability (Hase \& Kenyon 2007:113). Alternative assessment uses activities that reveal what students are able to do with the knowledge and skills obtained through learning, emphasising their abilities and strengths, instead of focussing on their weaknesses and what they do not know. Even failure can be seen as a valuable component of the learning process and not as an outcome (Educause Learning Initiative 2014). The learning process of constructing meaning through personal responsibility and choices (Garrison \& Vaughan 2008:9) gives students the freedom to explore ideas, to raise questions and objections or to construct meaning for them. Students can use alternative assessment tasks to develop attitudes and skills to become critical thinkers and to continue their learning beyond the narrow scope and time limit of a formal educational experience (Garrison \& Vaughan 2008:17).

Alternative assessment moves away from a measurement model towards student empowerment and the development of life-long learning (Wilson 2013:193). It focuses on tracking the individual student's growth and development over a period rather than comparing students and classes or year groups with one another (Huerta-Macias 1995). It should stimulate the development of higher-level cognitive skills that are aligned with the course purpose and intention (Biggs 2003), and provides opportunities for students to demonstrate their understanding of the content.
Measuring learning outcomes through a variety of assessment tasks provides for different learning styles, and takes into account the proficiencies and educational background as well as the potential grade levels of all students (HuertaMacias 1995:9). Effective assessment also focuses on students' strengths rather than on their weaknesses (Huerta-Macias 1995:9). It should require creative use of knowledge, skills and competencies.

Implementing alternative assessment is, however, labour intensive and time consuming. It requires a hands-on approach as well as continuous training and development opportunities for educators, which could be costly. These challenges can be converted into new and life-long learning opportunities, job creation, skills development and creation of new specialisation fields within the educational system.

\section{Research design and methodology}

Underlying the research is Academagogy, a studentcentred teaching theory that encourages life-long, selfdirected learning. Academagogy is an umbrella concept that can be used across diverse cultural and generational student backgrounds as well as within varying disciplines. This theory enables educators to select and use the most appropriate method in which to present both the study material and assessment tasks for each required learning experience and activity (Winter et al. 2009:3). This theory tailors teaching, learning and assessment to suit the studentcentred approach. It requires flexibility to comply with the students' own learning and life experiences (McAuliffe et al. 2008). Academagogy is a meshed model of pedagogy, andragogy and heutagogy. The combination of these major theoretical constructs into academagogy enhances good educational practices (Palloff \& Pratt 2003:xv).

Document analysis (Bowen 2009) is the research method selected for the investigation. In the knowledge based, network society, documents no longer only refers to ink and paper or electronic versions thereof. Even the concept of 'printed material' is currently expanding as 3D printing is escalating fast and in various sectors unrelated to what the term printing used to mean. The 'documents' investigated to serve as alternative assessment tools, could be defined as 'social facts' (Atkinson \& Coffey 1997:47) that are produced, shared and used in creative ways in society. The use of document analysis in the broader sense of including multimedia ${ }^{3}$ enable the process of exploration, analysis and evaluation of alternatives to traditional assessment tools and methods.

The team of observers included three theologians, one each from the three theology Departments at UNISA and two

3.Mayer (2001:2) defines multimedia as the presentation of material using both words and pictures. He expands this by explaining that 'words' include all materia words and pictures. He expands this by explaining that 'words' include all materia presented in verbal form (spoken or text) and pictures include all materia presented in visual form, including video, graphs and illustrations as well as three- $D$ constructions and creations. Gonzalez, Cranitch and Jo (2000:90) define multimedi as 'more than just a collection of sound, images, video and animations'. Multimedi is, according to them, 'a fusion of both the medium and the message to conceive interactive, multimodal information spaces effectively in the form of an artificial environment'. 
observers from other Departments within UNISA who, together with the researcher, completed a certificate course in the use of technology at the University of Maryland University College in 2013. Interrater reliability tests on a similar project assessed the degree to which the different observers provided constant estimates, working with the SECTIONS framework developed by Bates and Poole (2003). SECTIONS ( $\mathrm{S}=$ students; $\mathrm{E}=$ ease of use and reliability; $\mathrm{C}=$ costs; $\mathrm{T}=$ teaching and learning; $\mathrm{I}=$ interactivity; $\mathrm{O}=$ organisational issues; $\mathrm{N}=$ novelty; $\mathrm{S}=$ speed) was designed through the Instructional Systems Design procedure (Moore \& Kearsley 2011) and focusses on evaluating the use of technology for enhancing higher education. It provides a holistic framework to evaluate new and developing educational technology. The model is actually a broad framework or skeleton providing headings for educators to expand on. Course development team members who have different perspectives and come from different backgrounds and levels of expertise to evaluate educational resources are able to use this tool because it is both flexible and comprehensive (Boyes, Dowie \& Rumzan 2005:1). The SECTIONS model can be used repeatedly to expand tests and to consolidate previous results with more recent results in a continuous monitoring process, if needed.

The evaluation was done with the help of a checklist (based on the example of Underhill n.d.) to determine the potential fit between the learning outcomes, the learning activities identified to achieve these outcomes and the assessment methods that could be used to measure student progress in achieving the outcomes (Biggs 2003:162). Based on the evaluation, recommendations regarding the usability of each tool can be made.

\section{SECTIONS evaluation}

\section{Students}

Effective education needs to be student-centred. Bates and Poole (2003:80-87) identify three important issues related to students: demographics, different learning styles and affordable and convenient access to technology. The curriculum for a second year course, used in this investigation, is founded upon the R2D2 model of Bonk and Zhang (2006) that was originally developed as a tool to 'integrate various learning activities with appropriate technologies for effective online learning' (Bonk \& Zhang 2006:250). The R2D2 model was chosen because of its ability to address the diverse needs of students. This model is intended as a problem-solving wheel that represents all the phases of learning and learning styles and can guide all types of student preferences. It also helps educators to focus on the large range of opportunities that can be explored to present material in creative ways and get students involved with the learning process to practise what they have learned in their daily lives.

Student diversity is, however, not limited to learning styles. In the network society, students need to work in collaboration with each other and contribute through knowledge creation.
To cater for this, all aspects of blended learning ${ }^{4}$ must be taken into account, as they will differ for each individual student. Technology can help to bridge gaps in space and time, add choices regarding the use of media and expand activity options. Educators can use technology effectively to shorten the turnaround time on questions, problems and comments and also to identify and assist students of different competency levels.

Access to information and communication technology and the students' abilities to use these technologies are highly contested issues. The research of Liebenberg, Chetty and Prinsloo (2012) focuses on UNISA students' access to technology and their capabilities in using the technology within the discourse of the so-called 'digital divide'. They conclude that the level of access and capabilities amongst students are varied and complex, with no neat distinction between 'haves' and 'have-nots' when it comes to technology.

\section{Ease of use and reliability}

The focus of the rest of the frameworks' headings is on technology. The chosen assessment tools should be easy to use, not require extensive technical knowledge, must be user friendly and provide help and training information. Novice educators and students should be able to operate them within twenty minutes (Bates \& Poole 2003:87-92).

Technical reliability and stability present a constant problem in South Africa. Breakdowns in electricity supply, slow Internet speed and high costs (the next issue) are only a few of the many problems that constantly frustrate users of technology.

\section{Costs}

Bates and Poole (2003:92-95) identify individual items and drivers of costs. Individual costs include the license for use and copyright clearance and permissions as well as printing costs. Fortunately there are an ever increasing number of tools available to the educational sector which could be used without any licensing or copyright costs. Devices and access however, do come with a heavy price tag. Drivers of costs include the production of materials. Using technology, this aspect of costs could be reduced significantly when it comes to assessment with no need to print and distribute exam papers or hire exam venues. Students also benefit from the fact that they do not have to travel to or arrange for accommodation near exam venues. The use of technology can help to reduce costs to both service providers and stakeholders.

\footnotetext{
4.Blended learning consists of four components, namely the space blend, the time blend, the media blend and the activity blend (Littlejohn \& Pegler 2007). The space blend focusses on technology-mediated communication between students and educators and between students and other students. The time blend includes both real time (synchronously) and delayed time (asynchronously) activities. The medi real time (synchronously) and delayed time (asynchronously) activities. The media blend consists of different types of tools and resources, including multimedia. The activity blend reflects the educators' orchestration of a number of different learning activities that are included in the design of the module or programme. The values and importance of the individual components can be changed to fit the needs of all stakeholders and the programme whilst each component should be what it does best (Race 1999:15). The blended approach offers disciplined inquiry through reflective and collaborative activities whilst providing unlimited access to information (Garrison \& Vaughan 2008).
} 


\section{Teaching and learning (Bates \& Poole 2003:95-98)}

Flexibility ensures that the geographical gap between the students and educators, between students and their peers and students and the institution could be effectively narrowed or bridged. By implementing academagogy, educators ensure that the needs of stakeholders are catered for, a balanced blend can be produced and students have choices regarding the use of technology in all three aspects of effective education (teaching, learning and assessment).

\section{Interactivity (Bates \& Poole 2003:98-102)}

According to Anderson (2003:131), 'university education should go beyond content and include engagement with others to develop personal understanding'. Technology provides opportunities for interaction at all levels. Students have many opportunities for co-operation, practising and exercising skills, and liaising with others in creative ways to construct knowledge, whilst educators can provide intensive feedback and feed-forward guidance to individual students.

\section{Organisational issues (Bates \& Poole 2003:102-103)}

Not all universities currently support social media as educational tools due to the security risks involved. Normally, there are a number of tools available on the learning management systems (LMS) of the universities that can be helpful to educators wishing to incorporate technology into their teaching activities. Changes in some restrictive policies could also enhance and expand the use of technology in supporting fast and efficient service.

\section{Novelty (Bates \& Poole 2003:103-104)}

Educators must keep in mind that the newest technologies might not be tested for use in education yet, often do not perform as expected, and could be recalled or discontinued. It is therefore better to use beta versions of existing technology than to experiment with untested technologies. Novelty is not an important issue but both students and educators should use technology that is compatible with the world outside the university environment.

\section{Speed (Bates \& Poole 2003:104)}

Turnaround time is very important when it comes to assessment. Technology empowers educators to provide fast and efficient feedback. There are numerous assessment tools that can aid educators to mark, evaluate and grade students' work fast and effectively.

It seems as if technology can be used to assist educators with assessment, but it is important to evaluate the assessment tools before implementing them into the educational system in order to establish their compatibility and effectiveness. These assessment tools must be fit for purpose and linked to specific learning activities that support the outcomes of the module and course.

\section{Learning activities identified for assessment}

Five major types of learning activities were identified from the example course and used in this research. These learning activities are research, construction, reflection, action and cognition:

- Research activities include systematic investigation, study of information and reporting on gained knowledge and skills. Research can be linked to both lower and higher level thinking skills. Assessment tools to assess research capabilities could include information hunts and wiki's.

- Construction is a higher cognitive skill and implies that the students will have to design and create evidence to prove that they are competent in the tested areas. Assessment tools that can be used include word clouds, collages, posters, banners, flyers, ads, songs, poems and video.

- Reflection helps students to track their own progress and to become aware of changes in their personal attitudes, values, skills and behaviour. The students reflect on their own work or that of others in a variety of ways (prescribed or open) to internalise their learning. Reflection is linked with the higher cognitive level of evaluation. Selfassessments, blogs or journals can be used as effective reflective assessment tools.

- Learning should be an active process and student actions are therefore important for assessment purposes. It requires both lower and higher level skills to perform learning activities.

- Actions include creative, open-ended tasks and projects.

- Cognition involves mental processes including aspects like awareness, perception, reasoning and judgement and is a higher-level cognition activity. Mind maps fill the gaps and debates serve as examples of assessment for this type of learning activity.

Each one of the learning activities is linked to different assessment tools that can effectively assess that specific activity. These assessment tools are examples of technology driven assessment methods that can assess student competencies to achieve the learning outcomes of the course. It is possible to expand this research by adding assessment tools to some or to all of the listed learning activities or by expanding the number of learning activities.

\section{Assessment of individual tools}

Ten assessment tools were linked to the learning activities and individually evaluated according to the SECTIONS framework. Included in the evaluation are the following: effective education, learning styles, digital literacies, blended learning and Blooms' taxonomy. The assessment tools that were subjected to the evaluation are:

- Edublog allows users to create and manage student and educator blogs within a secure environment. A blog is a personal website with its own URL in the form of an online journal (that can include multimedia), posted in reverse chronological order. Educators can keep track of students' progress and development and it provides ample opportunity for reflection as learning activity. 
- Weebly for education is a free web-hosting service that allows 40 student accounts. Additional accounts can be bought. Private and public options are available. Personal web pages are student-centred, cover a wide variety of content, allow users to drag and drop content (including multimedia) and provide opportunities for reflection. Weebly includes a blog option and can also be used for student portfolios. Educators can monitor student accounts from a central dashboard and pages can be password protected.

- SurveyMonkey is an online survey tool that can also be used in printed format. Free and premium options are available. It allows users to design customised surveys and to collect and analyse responses from open or targeted audiences. It provides researchers with statistical information on the surveys done. This tool is linked to research as learning activity. Caution must be taken to ensure that the surveys are constructed correctly and ethical clearance should be obtained from all applicable stakeholders before any research is conducted.

- Diigo is a social bookmarking research and knowledge sharing tool that allows users to make personal notes and highlight text on web pages, create lists and write annotated reviews. This tool is used to assess research learning activities, promote effective referencing and summarise important information. Free and premium options are available.

- Wordle is a tool that generates word clouds from provided text, using Java. It can be used to summarise and prioritise research results or to convert content to visual data. Users can demonstrate their knowledge and understanding of content and express creativity with this tool. Wordle is used as an assessment tool for the creation and construction of unique content.

- Glogster EDU is a free online educational service to create interactive 'posters' of research results and learning activities, composed of text, graphics, sounds and video, with a commenting facility for peer review and assessment. The premium service provides privacy and security. It can be used for creative construction of content.

- Wikispaces is a hosting platform providing an expandable collection of interlinked web pages, a hypertext system for storing and modifying information, a database with visual page editing and discussion areas for collaborative working and active learning opportunities. This tool encourages peer learning and collaboration. It provides for creative and active learning. It is difficult to navigate this tool on mobile devices. For privacy and security, premium options are recommended.

- YouTube is a free video-sharing site where users can upload, view and share videos. It also has an educational branch that could be used for teaching and learning. It enhances creativity and active learning opportunities.

- Coggle is a free mind-mapping tool that produces hierarchically structured documents that can be personalised, downloaded, edited and shared. This tool is linked with cognition as learning activity. It encourages peer learning and sharing of knowledge and insight.
- Twitter is a free online social networking and microblogging tool that enables users to interact through short multimedia messages. This tool is linked with cognition as learning activity. Twitter has the right to use and even sell all content (Delsack 2012) and students and educators must be informed accordingly.

The response key for evaluation: each question is answered by choosing either 'Yes' (Y) or 'No' (N) (Table 1). The level of importance relates to the key or core issues of the course purpose, learning outcomes and content:

- High (H): linked to the purpose and learning outcomes of the course

- Medium (M): skills or knowledge supporting the general aim of the course

- Low (L): not necessary to complete the course successfully.

The SECTIONS evaluation showed that all the tested tools could enhance effective education and can be used as alternative assessment methods. The tools are free, easy to set up and use and almost all are workable from mobile devices. The tools can be used independent of time and space, and its flexibility adds convenience. It speeds up communication and turnaround times. All the tested tools have a proven record of use in the educational environment. All the tested tools can be used effectively as assessment options and they can enhance interaction, active learning and encourage creativity. These tools can promote digital literacy competencies and skills that can be used outside of the educational environment. The tools provide timesaving, environmental friendly assessment options.

The different tools offer opportunities to focus on specific learning activities in fine detail. Educators can assess a wide variety of content and competencies such as individual skills, cognitive abilities, progress and change in values. Educators can use these assessment methods to timely identify students who need extra support. Educators can respond easily and speedily to students' submissions and in most cases, the tools can be used for formative and summative assessment as well as tutoring.

Students are able to develop and refine higher order thinking skills, problem solving skills, literacy skills and communication skills. They can be creative in their responses and have choices on how to respond to assessment tasks. They are further provided with opportunities to practise active learning and to monitor their own learning journey. Technology and the use of alternative assessment options enable students to become active contributors and knowledge creators. Technology enables both educators and students to update, expand or correct content frequently and easily. Educators and students can be challenged to explore and learn in more than one way; not only content or required competencies, but also new skills.

Although there are some potential problems regarding the tested tools, these are more or less of the same level 
TABLE 1: Assessment of individual tools.

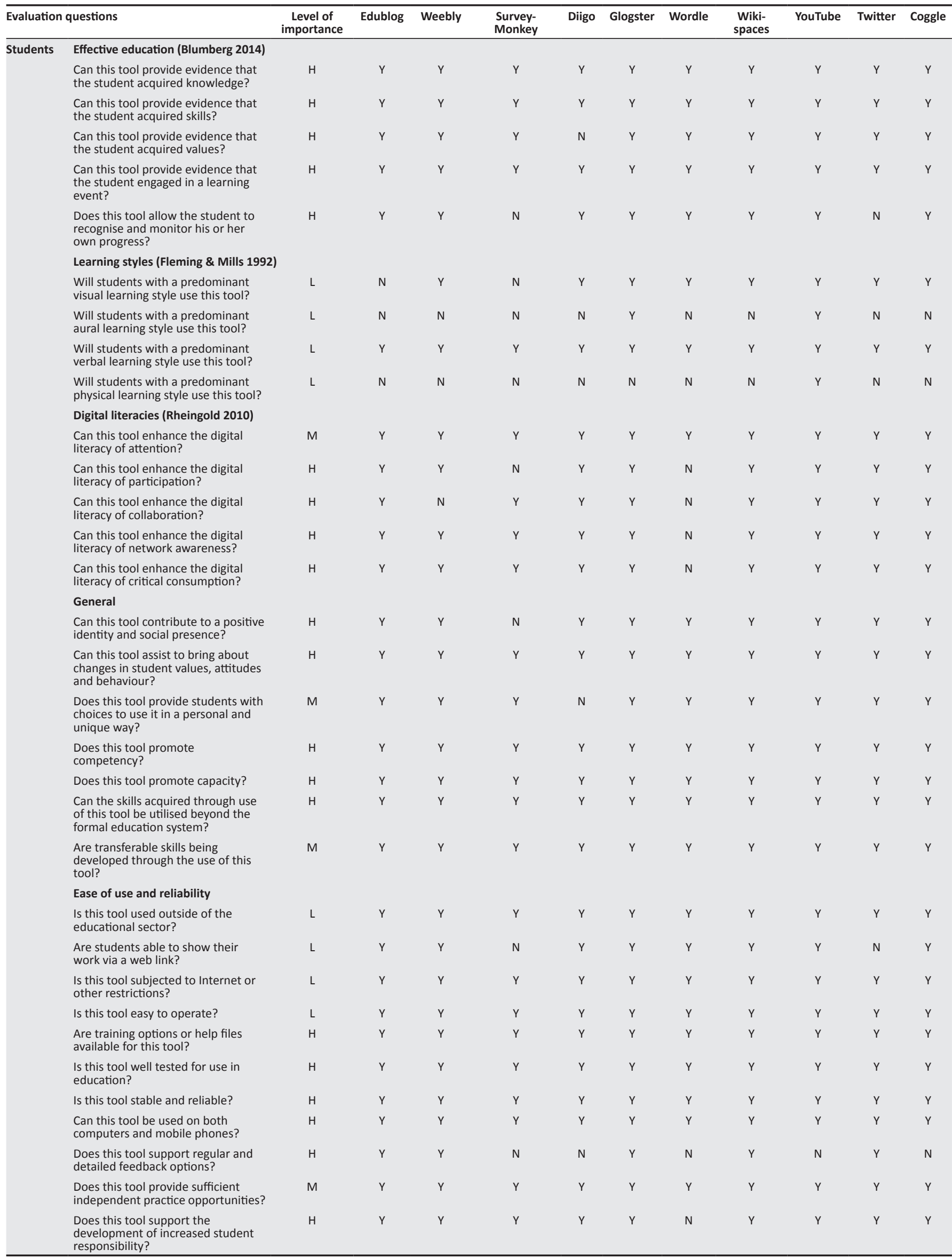


TABLE 1 (Continues...): Assessment of individual tools.

\begin{tabular}{|c|c|c|c|c|c|c|c|c|c|c|c|c|}
\hline \multicolumn{2}{|c|}{ Evaluation questions } & \multirow{2}{*}{$\begin{array}{l}\text { Level of } \\
\text { importance }\end{array}$} & \multirow[t]{2}{*}{ Edublog } & \multirow[t]{2}{*}{ Weebly } & \multirow{2}{*}{$\begin{array}{l}\text { Survey- } \\
\text { Monkey }\end{array}$} & \multirow[t]{2}{*}{ Diigo } & \multirow[t]{2}{*}{ Glogster } & \multirow[t]{2}{*}{ Wordle } & \multirow{2}{*}{$\begin{array}{l}\text { Wiki- } \\
\text { spaces }\end{array}$} & \multirow[t]{2}{*}{ YouTube } & \multirow[t]{2}{*}{ Twitter } & \multirow[t]{2}{*}{ Coggle } \\
\hline & Costs & & & & & & & & & & & \\
\hline & Can students use this tool for free? & $\mathrm{H}$ & $\mathrm{Y}$ & Y & Y & Y & Y & Y & Y & Y & Y & Y \\
\hline & $\begin{array}{l}\text { Can this tool be used without a } \\
\text { licensing fee? }\end{array}$ & $\mathrm{H}$ & Y & Y & Y & Y & Y & Y & Y & Y & Y & Y \\
\hline \multirow{32}{*}{$\begin{array}{l}\text { Teaching } \\
\text { and } \\
\text { learning }\end{array}$} & Blended learning (sit in) & & & & & & & & & & & \\
\hline & $\begin{array}{l}\text { Does this tool allow educators and } \\
\text { students to work anywhere? }\end{array}$ & $\mathrm{H}$ & Y & Y & Y & Y & Y & Y & Y & Y & Y & Y \\
\hline & $\begin{array}{l}\text { Does this tool allow educators and } \\
\text { students to work anytime? }\end{array}$ & $\mathrm{H}$ & Y & Y & Y & Y & Y & Y & Y & Y & Y & $\mathrm{Y}$ \\
\hline & Blooms' taxonomy (Bloom et al. 1956 & & & & & & & & & & & \\
\hline & $\begin{array}{l}\text { Does this tool stimulate students to } \\
\text { remember information? }\end{array}$ & L & $\mathrm{N}$ & $\mathrm{N}$ & $\mathrm{N}$ & Y & Y & Y & Y & Y & $\mathrm{N}$ & $\mathrm{Y}$ \\
\hline & $\begin{array}{l}\text { Does this tool help students to } \\
\text { show that they understand the } \\
\text { information? }\end{array}$ & $\mathrm{H}$ & Y & Y & $\mathrm{N}$ & Y & Y & Y & Y & Y & Y & Y \\
\hline & $\begin{array}{l}\text { Can this tool provide evidence that } \\
\text { students can apply what they have } \\
\text { learned? }\end{array}$ & $\mathrm{H}$ & Y & Y & Y & $\mathrm{N}$ & Y & Y & Y & Y & Y & Y \\
\hline & $\begin{array}{l}\text { Does this tool allow students to } \\
\text { analyse material? }\end{array}$ & $\mathrm{H}$ & Y & Y & Y & Y & Y & Y & Y & Y & Y & Y \\
\hline & $\begin{array}{l}\text { Can this tool be used for evaluation } \\
\text { of information? }\end{array}$ & $\mathrm{H}$ & Y & Y & Y & Y & Y & Y & Y & Y & Y & $Y$ \\
\hline & $\begin{array}{l}\text { Can this tool be used to create } \\
\text { original material? }\end{array}$ & $M$ & $Y$ & Y & Y & $Y$ & Y & Y & Y & Y & Y & Y \\
\hline & $\begin{array}{l}\text { Can this tool be used to } \\
\text { demonstrate critical thinkingt? }\end{array}$ & $\mathrm{H}$ & $Y$ & Y & Y & $Y$ & Y & Y & Y & Y & Y & $Y$ \\
\hline & General & & & & & & & & & & & \\
\hline & $\begin{array}{l}\text { Does this tool allow students to link } \\
\text { existing knowledge and skills with } \\
\text { new knowledge and skills? }\end{array}$ & $\mathrm{H}$ & $Y$ & Y & Y & $Y$ & Y & Y & Y & Y & Y & $Y$ \\
\hline & $\begin{array}{l}\text { Can this tool be used for formative } \\
\text { assessment purposes? }\end{array}$ & $\mathrm{H}$ & $Y$ & Y & Y & $Y$ & Y & Y & Y & Y & Y & $Y$ \\
\hline & $\begin{array}{l}\text { Can this tool be used for summative } \\
\text { assessment purposes? }\end{array}$ & $M$ & $Y$ & Y & Y & $Y$ & Y & Y & Y & Y & Y & Y \\
\hline & $\begin{array}{l}\text { Does this tool allow educators to } \\
\text { provide fast and efficient feedback? }\end{array}$ & $\mathrm{H}$ & Y & Y & $\mathrm{N}$ & $\mathrm{N}$ & Y & Y & $Y$ & N & Y & $\mathrm{N}$ \\
\hline & $\begin{array}{l}\text { Does this tool allow educators } \\
\text { to provide efficient feed-forward } \\
\text { support? }\end{array}$ & $\mathrm{H}$ & $Y$ & Y & Y & $Y$ & Y & Y & Y & Y & Y & $\mathrm{N}$ \\
\hline & $\begin{array}{l}\text { Can this tool be used to } \\
\text { demonstrate the students' } \\
\text { competency regarding core issues } \\
\text { (such as mastery of content, } \\
\text { historical literacy, communication } \\
\text { skills)? }\end{array}$ & $\mathrm{H}$ & Y & Y & Y & $Y$ & Y & Y & Y & Y & Y & $Y$ \\
\hline & $\begin{array}{l}\text { Does this tool promote active } \\
\text { learning? }\end{array}$ & $\mathrm{H}$ & Y & Y & Y & $Y$ & Y & Y & Y & Y & Y & $\mathrm{Y}$ \\
\hline & Interactivity & & & & & & & & & & & \\
\hline & $\begin{array}{l}\text { Does this tool support interaction } \\
\text { between students? }\end{array}$ & $M$ & $Y$ & Y & $\mathrm{N}$ & Y & Y & N & $Y$ & Y & Y & $Y$ \\
\hline & $\begin{array}{l}\text { Does this tool support interaction } \\
\text { between students and educators? }\end{array}$ & $\mathrm{H}$ & Y & Y & $\mathrm{N}$ & $\mathrm{N}$ & Y & $\mathrm{N}$ & $Y$ & $\mathrm{~N}$ & Y & $\mathrm{Y}$ \\
\hline & $\begin{array}{l}\text { Does this tool allow for sharing and } \\
\text { collaboration? }\end{array}$ & $\mathrm{H}$ & Y & $\mathrm{N}$ & $\mathrm{N}$ & $Y$ & Y & Y & $\mathrm{Y}$ & Y & Y & Y \\
\hline & $\begin{array}{l}\text { Will the students' work be in the } \\
\text { public domain? }\end{array}$ & L & Y & $\mathrm{N}$ & $\mathrm{N}$ & $\mathrm{Y}$ & Y & Y & $\mathrm{Y}$ & Y & Y & $\mathrm{Y}$ \\
\hline & Organisational issues & & & & & & & & & & & \\
\hline & $\begin{array}{l}\text { Is this tool linked to the university } \\
\text { (Learning Management Systems)? }\end{array}$ & $\mathrm{L}$ & $\mathrm{N}$ & $\mathrm{N}$ & $\mathrm{N}$ & $\mathrm{N}$ & $\mathrm{N}$ & $\mathrm{N}$ & $\mathrm{N}$ & $\mathrm{N}$ & $\mathrm{N}$ & $\mathrm{N}$ \\
\hline & $\begin{array}{l}\text { Is the use of this tool in line with the } \\
\text { university policies? }\end{array}$ & $\mathrm{H}$ & $\mathrm{Y}$ & Y & Y & $Y$ & Y & Y & $Y$ & Y & Y & $Y$ \\
\hline & $\begin{array}{l}\text { Is there a way to retrieve material or } \\
\text { information if this technology fails } \\
\text { or is replaced? }\end{array}$ & $\mathrm{H}$ & $\mathrm{N}$ & $\mathrm{N}$ & $\mathrm{N}$ & $\mathrm{N}$ & $\mathrm{N}$ & $\mathrm{N}$ & $\mathrm{N}$ & $\mathrm{N}$ & $\mathrm{N}$ & $\mathrm{N}$ \\
\hline & $\begin{array}{l}\text { Will students manage their own } \\
\text { accounts? }\end{array}$ & $\mathrm{L}$ & $\mathrm{Y}$ & Y & Y & Y & Y & Y & $\mathrm{Y}$ & $\mathrm{Y}$ & Y & $\mathrm{Y}$ \\
\hline & Novelty & & & & & & & & & & & \\
\hline & $\begin{array}{l}\text { Can the use of this tool provide } \\
\text { new learning experiences for the } \\
\text { students? (do new things) }\end{array}$ & M & $Y$ & Y & Y & $\mathrm{Y}$ & Y & Y & $Y$ & Y & Y & $Y$ \\
\hline & $\begin{array}{l}\text { Are there examples of use of this } \\
\text { tool in the educational context? }\end{array}$ & $M$ & $\mathrm{Y}$ & Y & Y & Y & Y & Y & $\mathrm{Y}$ & Y & Y & $\mathrm{Y}$ \\
\hline
\end{tabular}


TABLE 1 (Continues...): Assessment of individual tools.

\begin{tabular}{|c|c|c|c|c|c|c|c|c|c|c|c|}
\hline Evaluation questions & $\begin{array}{l}\text { Level of } \\
\text { importance }\end{array}$ & Edublog & Weebly & $\begin{array}{l}\text { Survey- } \\
\text { Monkey }\end{array}$ & Diigo & Glogster & Wordle & $\begin{array}{l}\text { Wiki- } \\
\text { spaces }\end{array}$ & YouTube & Twitter & Coggle \\
\hline $\begin{array}{l}\text { Does this tool provide opportunities } \\
\text { to be creative and innovative? }\end{array}$ & $\mathrm{H}$ & Y & $Y$ & $Y$ & Y & Y & $Y$ & $Y$ & $Y$ & $\mathrm{Y}$ & Y \\
\hline \multicolumn{12}{|l|}{ Speed } \\
\hline $\begin{array}{l}\text { Can educators make quick and easy } \\
\text { comments by using this tool? }\end{array}$ & $\mathrm{H}$ & Y & Y & Y & Y & Y & Y & Y & $\mathrm{Y}$ & Y & Y \\
\hline $\begin{array}{l}\text { Can students quickly and easily } \\
\text { update information using this tool? }\end{array}$ & $\mathrm{H}$ & Y & Y & Y & Y & Y & $\mathrm{Y}$ & Y & $\mathrm{Y}$ & $\mathrm{Y}$ & Y \\
\hline $\begin{array}{l}\text { Is it possible to respond quickly } \\
\text { using this tool? }\end{array}$ & $\mathrm{H}$ & Y & Y & Y & Y & Y & Y & Y & $\mathrm{N}$ & $\mathrm{Y}$ & Y \\
\hline $\begin{array}{l}\text { Will the use of this tool enable } \\
\text { educators and students to safe } \\
\text { time? }\end{array}$ & L & $\mathrm{N}$ & Y & Y & Y & $\mathrm{N}$ & Y & Y & $\mathrm{N}$ & $\mathrm{Y}$ & $Y$ \\
\hline
\end{tabular}

L, low; M, medium; $\mathrm{H}$, high; $\mathrm{Y}$, yes; $\mathrm{N}$, no.

$\dagger$, Critical thinking is a complex concept. Moore (2013:506) describes it as consisting of seven elements: judgement, a sceptical and provisional view of knowledge, simple originality, careful and sensitive reading of texts, rationality, the adopting of an ethical and activist stance, and self-reflexivity.

as problems that could occur with the use of traditional assessment methods. Students must be informed about alternative assessment options and choices. Security, privacy, copyright issues and unethical behaviour pose the most important potential threats. Educators and students must ensure that they are up to date with policies and practices in this regard. Educators should inform and instruct students on the possible dangers and pitfalls of working with technology and creating material that is publicly visible. They should ensure that ethical codes of conduct are in place for all tools and all courses and that all students are aware of them and adhere to them. Educators must make it clear to students what the aim of the assessment and the choice of the assessment tool is and what features of each tool will be used. Educators must provide clear guidelines to all students on how and when they will monitor, interact, provide feedback and marks to assessment tasks. Students must be advised to regularly make and store back-up copies of all their work.

It must also be kept in mind that the development of course material and the initial implementation of alternative assessment methods could be time consuming and stressful to educators. Due to frequent changes and development in technology, educators could be in need of continuous training opportunities to be able to keep up to date with new and developing tools that could be used for alternative assessment.

The most significant problems not linked to the assessment tools itself are costs and connectivity. These aspects will have to be investigated and the problems urgently solved by the government and private service providers before all students will benefit from the choices provided to them through the use of alternative assessment methods.

This research is a limited investigation on the potential move to technology driven alternative assessment methods for higher education. Due to the expansions and speed of development in technology, a continuous research project on this issue should be in place in the theology clusters or faculties of the South African universities. The current research results can provide a foundation on which expansions and new investigations can be done.

\section{Conclusion}

Effective education should enable students to become independent, build their confidence and increase their motivation levels. It should assist students to reach their full potential regarding the specific module or programme and eventually turn graduates into life-long learners capable of becoming positive change agents in their respective communities. Technology opens up numerous possibilities for alternative assessment methods to build capacity and enhance educational experiences for students as well as expanding the influence of education on communities through transferal of knowledge, skills and values.

Traditional paper based assessment tools such as multiple choice questions, essay-type assignments and venue-based exams often do not measure if learning has occurred and if skills and knowledge gained can be transferred or applied in real-life situations.

The main goal of the research was to identify and test a number of alternative assessment tools that provides students with choices on how they provide evidence of learning. Ten tools were linked to five general learning activities to ensure that the assessment methods chosen would be fit for purpose and could be used for authentic assessment. The tools were tested with the help of the SECTIONS framework, which focuses on the use of technology in education. The ability to be used for different learning styles, levels of cognitive development, as well as skill and competency development were evaluated. Interactivity, ease of use and the speed factors were also evaluated. The research showed that all the technology driven alternative assessment tools that were evaluated could be used successfully in a studentcentred higher education environment to provide effective education.

\section{Acknowledgements Competing interests}

The author declares that she has no financial or personal relationships which may have inappropriately influenced her in writing this article. 


\section{References}

Anderson, T., 2003, 'Modes of interaction in distance education: Recent development and research questions', in M.G. Moore \& W.G. Anderson (eds.), Handbook of distance education, pp. 129-144, Lawrence Erlbaum Associates Publishers, Mahwah, NJ.

Assessment Reform Group (ARG), 2002, Assessment for learning: 10 principles. Research-based principles to guide classroom practice, viewed 13 February 2013, from http://www.hkeaa.edu.hk/DocLibrary/SBA/HKDSE/Eng_DVD/doc/ Afl_principles.pdf

Astin, A.W., Banta, T.W., Cross, K.P., El-Khawas, E., Ewell, P.T., Hutchings, P. et al., 1996 ' 9 principles of good practice for assessing student learning', American Association for Higher Education Assessment Forum, viewed 13 February 2013, from http:// www.aahe.org/principl.htm

Atkinson, P.A. \& Coffey, A., 1997, 'Analysing documentary realities', in D. Silverman (ed.), Qualitative research: Theory, method and practice, pp. 45-62, Sage, London.

Bates, A. \& Poole, G., 2003, Effective teaching with technology in higher education, Jossey-Bass, San Francisco, CA.

Biggs, J., 2003, 'Aligning teaching and assessing to course objectives', Teaching and Learning in Higher Education: New trends and Innovations, University of Aveiro, viewed 07 April 2014, from http://www.ucsc.cmb.ac.lk/wiki/images/2/2c/CA1. pdf

Bloom, B.S., Engelhart, M.D., Furst, E.J., Hill, W.H. \& Krathwohl, D.R., 1956, Taxonomy of educational objectives: The classification of educational goals. Handbook Cognitive domain, David McKay Company, New York, NY.

Blumberg, P., 2014, Assessing and improving your teaching: Strategies and rubrics for faculty growth and student learning, Jossey-Bass, San Francisco, CA.

Bonk, C.J. \& Zhang, K., 2006, 'Introducing the R2D2 model: Online learning for the diverse learners of this world', Distance Education 27(2), 249-264. http://dx.doi. org/10.1080/01587910600789670

Bowen, G.A., 2009, 'Document analysis as a qualitative research method', Qualitative Research Journal 9(2), 27-40. http://dx.doi.org/10.3316/QRJ0902027

Boyes, J., Dowie, S. \& Rumzan, I., 2005, 'Using the SECTIONS framework to evaluate flash media', Innovate 2(1), viewed 23 April 2012, from http://www. innotaveonline.info/index. php?view=article\&id $=55$

Bransford, J.D., Brown, A.L. \& Cocking, R.R. (eds.), 2000, How people learn: Brain mind, experience and school: Expanded edition, National Academy Press, Washington, DC.

Braun, H., Kanjee, A., Bettinger, E. \& Kremer, M., 2006, 'Improving education through assessment, innovation and evaluation', viewed 23 April 2012, from http://www. amacad.org/publications/braun.pdf

Cochrane, T., Antonczak, L., Gordon, A., Sissons, H. \& Withell, A., 2012, 'Heutagogy and mobile social media: Post Web 2.0 pedagogy', viewed 12 February 2014, from www.ascilite.org/conferences/Wellington12/2012/images/custom/cochrane, thomas_-_heutagogy_and_mobile.pdf

Cooper, L., Orrell, J. \& Bowden, M., 2010, Work integrated learning: A guide to effective practice, Routledge, London.

Delsack, C., 2012, 'Who owns photos and videos posted on Facebook, Instagram or Twitter?', viewed 25 April 2013, from http://www.nyccounsel.com/businessblogs-websites/who-owns-photos-and-videos-posted-on-facebook-or-twitter/

Doyle, T., 2011, Learner-centered teaching: Putting the research on learning into practice, Stylus, Sterling.

Educause Learning Initiative, 2014, '7 things you should know about ... competency based education', viewed 12 February 2015, from http://www.educause. edu/library/resources/7-things-you-should-know-about-competency-basededucation

Eshet, Y., 2012, 'Thinking in the digital era: A revised model for digital literacy', in E.B. Cohen (ed.), Issues in informing science and information technology, vol. 9, pp. 267-276, Informing Science Press, Santa Rosa, CA.

Fink, L.D., 2013, Creating significant learning experiences. An integrated approach to designing college courses, Jossey-Bass, San Francisco, CA.

Fleming, N.D. \& Mills, C., 1992, VARK: A guide to learning styles, viewed 23 October 2013, from http://www.vark-learn.com/English/index.asp

Garrison, D.R. \& Vaughan, N.D., 2008, Blended learning in higher education Framework, principles and guidelines, Jossey-Bass, San Francisco, CA.

Gonzalez, R., Cranitch, G. \& Jo, J., 2000, 'Academic directions of multimedia education', Communications of the ACM, January 43(1), 89-95. http://dx.doi. org/10.1145/323830.323849

Greenhow, C., Robelia, B. \& Hughes, J.E., 2009, 'Learning, teaching and scholarship in a digital age: Web 2.0 and classroom research: What path should we take now?', Educational Researcher 38, viewed 12 February 2012, from http://edr.sagepub. com/content/38/4/246
Hase, S. \& Kenyon, C., 2007, 'Heutagogy: A child of complexity theory', Complicity: An International Journal of Complexity \& Education 4(1), 111-117, viewed 12 February 2012, from http://www.complexityandeducation.ualberta.ca/journal. htm

Huerta-Macias, A., 1995, 'Alternative assessment: Responses to commonly asked questions', TESOL Journal 5(1), 8-10.

Ice, P., 2010, 'The future of learning technologies. Transformational developments', in M.F. Cleveland-Innes \& D.R. Garrison (eds.), An introduction to distance education. Understanding teaching and learning in a new era, pp. 155-164, Routledge, New York, NY.

Jukes, I. \& Dosaj, A., 2005, 'Understanding digital Kids (DKs): Teaching and learning in the new digital landscape', viewed 23 April 2013, from http://www.researchgate. net/publication/228699507 Understanding_Digital_Kids_(DKs) Teaching learning_in_the_new_digital_landscape

Koltay, T., 2011, 'The media and the literacies: Media literacy, information literacy, digital', Media, Culture \& Society 33(2), 211-221. http://dx.doi.org/ 10.1177/0163443710393382

Liebenberg, H., Chetty, Y. \& Prinsloo, P., 2012, 'Student access to and skills in using technology in an ODL context', International Review of Research in Open and Distance Learning 13(4), viewed 13 March 2014, from http://www.irrodl.org/ index.php/orrodl/article/view/1303

Littlejohn, A. \& Pegler, C., 2007, Preparing for blended e-learning, Routledge, New York, NY.

Mayer, R.E., 2001, Multimedia learning, Cambridge University Press, Cambridge.

Mayer-Mihalski, N. \& DeLuca, M.J., 2009, 'Effective education leading to behavior change', viewed 23 April 2014, from http://www.paragonrx.com/experience/ white-papers/effective-education-leading-to-behavior-change/

McAuliffe, M., Hargreaves, D., Winter, A. \& Chadwick, G., 2008, 'Does pedagogy stil rule?', Australasian Journal of Engineering Education 15(1), 13-18.

Moore, T., 2013, 'Critical thinking: Seven definitions in search of a concept', Studies in Higher Education 38(4), 506-522. http://dx.doi.org/ 10.1080/03075079.2011.586995

Moore, M.G. \& Kearsley, G., 2011, Distance education: A systems view and model, Wadsworth, Belmont, TN.

North Central Regional Educational Laboratory, n.d., 'Alternative assessment', viewed 23 April 2013, from www.ncrel.org/sdrs/areas/issues/methods/assment/as8lk30. htm

Oliver, E., 2012, 'Closing gaps in open distance learning for theology students', Acto Theologica 32(2), 162-183. http://dx.doi.org/10.4314/actat.v32i2.10

Palloff, R.M. \& Pratt, K., 2003, The virtual student. A profile and guide to working with online learners, Jossy-Bass, San Francisco, CA.

Pariser, E., 2011, The filter bubble. What the Internet is hiding from you, Viking, London.

Pillay, P., 2010, 'Linking higher education and economic development. Implications for Africa from three successful systems', Centre for Higher Education Transformation, Wynberg.

Prinsloo, P., 2011, 'ODL Communiqué 47', viewed 12 February 2011, from http://uir. UNISA.ac.za/bitstream/handle/10500/4003/ODL\%20Communique\%2047,\%20 9\%20February\%202011.pdf?sequence+1

Race, P. (ed.), 1999, 2000 tips for lecturers, Kogan Page Limited, London.

Ramsden, P., 1992, Learning to teach in higher education, Routledge, London.

Rheingold, H., 2010, 'Attention and other 21st century social media literacies', EDUCAUSE Review, Sept-Oct.

Underhill, C. n.d., 'Assessing technology. Using the SECTIONS model', Centre for teaching, learning and technology, University of British Colombia, viewed 12 February 2014, from http://wiki.ubc.ca/images/1/19/SECTIONS_Framework.pdf

Warschauer, M. \& Matuchniak, T., 2010, 'New technology and digital worlds: Analyzing evidence of equity in access, use, and outcomes', Review of Research in Education 34, 179-224. http://dx.doi.org/ 10.3102/0091732X09349791

Wheeler, S., 2014, 'Digital learning futures. 3 things you should know about the future of learning', paper presented at the minicon Reform Symposium conference, Online Global, 04 May, viewed 23 September 2014, from http://www.slideshare. net/timbuckteeth/digitallearning-futures-3-things-about-future-learning?next slideshow $=1$

Wilson, A., 2013, 'Feedback as a transformative tool. The role of feedback in learning and assessment', in K. Coleman \& A. Flood (eds.), Marking time. Leading and managing the development of assessment in higher education, pp. 193-200, Common ground Publishing, Champaign, IL.

Winter, A., Auliffe, M., Chadwick, G. \& Hargreaves, D., 2009, 'Implementing academagogy: The first case study', 20th Australasian association for engineering education conference proceedings, University of Adelaide, pp. 992-997, 06-09 December. 